\title{
PENGARUH MOTIVASI INTRINSIK, KOMPETENSI AUDITOR DAN KEPUASAN KERJA TERHADAP KINERJA AUDITOR EKSTERNAL (SURVEI PADA AUDITOR BPK-RI PERWAKILAN PROVINSI SULAWESI UTARA)
}

\author{
Iriany Neghe $^{1}$, Jullie Sondakh ${ }^{2}$, Meily Kalalo $^{3}$ \\ ${ }^{1,2,3}$ Fakultas Ekonomi dan Bisnis, Jurusan Akuntansi, Universitas Sam Ratulangi, Jl.Kampus Bahu, Manado, \\ 95115, Indonesia
}

E-mail : anyneghe10@gmail.com

\begin{abstract}
Auditor's performance is an important thing in order to reflect the quality of work done by auditor in conducting the examination of financial statements objectively. This research is aimed to determine the influence of intrinsic motivation, competence of auditor and job satisfaction on external auditor's performance. Sample on this research are auditors that work in Indonesia's Supreme Audit Institution Representative of North Sulawesi Province. The data in this research is primary data that collected by using questionnaires given to auditors. The method of analysis that used to test the hypothesis is multiple regression analysis using SPSS version 23. The result showed that intrinsic motivation has a positive effect on external auditor's performance, auditor's competence has a positive effect on external auditor's performace, job satisfaction has a positive effect on external auditor's performance. Beside that, intrinsic motivation, auditor's competence and job satisfaction simultaneously effect the external auditor's performance.

Keywords: Intrinsic Motivation, Auditor's competence, Job Satisfaction, External Auditor Performance.
\end{abstract}

\section{PENDAHULUAN}

Saat ini tuntutan masyarakat terhadap pelaksanaan transparansi dan akuntabilitas semakin meningkat agar terciptanya tata pemerintah yang baik (good governance). Untuk memenuhi tuntutan tersebut maka dalam pengelolaan keuangan negara dibutuhkan lembaga/badan independen untuk dapat melakukan pemeriksaan. Dalam melakukan pemeriksaan keuangan negara seorang auditor dapat bersikap objektif terhadap semua kegiatan yang diperiksa dan bertindak secara independen. Seorang auditor dituntut untuk dapat melakukan pemeriksaan sesuai dengan ketentuan dan standar audit yang berlaku. Hal ini dimaksudkan agar auditor dalam bekerja mampu meningkatkan kinerjanya. Dalam meningkatkan kinerjanya, auditor dihadapkan pada berbagai tantangan untuk mewujudkan transparansi dan akuntabilitas. Oleh karena itu kualitas hasil audit sangat diperhatikan oleh masyarakat umum yang digunakan sebagai parameter kinerja auditor tersebut.

Panjaitan dan Jatmiko (2014) mengatakan bahwa karyawan jika bekerja keras dan melakukan pekerjaannya dengan baik, sering diartikan karyawan tersebut memiliki motivasi kerja yang tinggi, sebaiknya jika karyawan tidak melakukan pekerjaannnya dengan baik atau tidak cukup keras mencoba maka karyawan tidak memiliki motivasi terhadap pekerjaannya. Motivasi tersebut dapat di pengaruhi dari luar (ekstrinsik) maupun dari dalam diri (intrinsik). Manfaat motivasi intrinsik adalah menciptakan gairah kerja, sehingga kinerja meningkat. Sementara itu, manfaat yang diperoleh karena bekerja dengan orang-orang yang termotivasi adalah pekerjaan dapat diselesaikan dengan tepat. Artinya pekerjaan diselesaikan sesuai standar yang benar dan dalam skala waktu yang sudah ditentukan, serta orang senang melakukan pekerjaannya (Arep \& Tanjung, 2013). Rich, Lepin \& Crawford (2010) juga mengatakan bahwa motivasi intrinsik berfokus pada upaya individu dan ketekunannya yang 
didedikasikan untuk mempertahankan keberadaan dan wewenangnya. Dengan demikian, auditor yang terdorong secara intrinsik akan menyenangi pekerjaan yang memungkinkannya mengerahkan seluruh kemampuan dan keahliannya bekerja dengan tingkat otonomi yang tinggi dan tidak perlu diawasi dengan ketat.

Selain menjadi seorang profesional yang memiliki sikap profesionalisme, auditor harus memiliki pengetahuan yang memadai dalam profesinya guna mendukung pekerjaannya dalam melakukan setiap pemeriksaan. Lee dan Stone (1995) dalam Efendy (2010) mendefinisikan kompetensi sebagai keahlian yang cukup yang secara eksplisit dapat digunakan untuk melakukan audit secara objektif. Tentunya dalam melaksanakan audit yang berkualitas, auditor harus memiliki kompetensi dalam melaksanakan pengawasan yang dibebankan kepadanya. Hal itu penting karena selain mampu menghasilkan kinerja yang baik dalam mematangkan pertimbangan dalam penyusunan laporan hasil pemeriksaan, juga penting untuk mencapai harapan pemerintah yang bersih dan transparan sehingga mampu mengurangi angka korupsi yang terjadi dan memperbaiki keadaan perekonomian.

Di Indonesia, kasus Akuntan Publik JAS juga terbukti melakukan kesalahan dalam mengaudit laporan keuangan PT Great River Internasional, Tbk. Kantor akuntan publik ini tidak melakukan koreksi terhadap kelebihan pencatatan penjualan PT. Great River Internasional, Tbk karena pihaknya mengaku telah mengaudit laporan keuangan perusahaan tersebut sesuai dengan metode pencatatan periode sebelumnya. Dengan begitu auditor yang memiliki kewenangan di PT Great River Internasional, Tbk ini dianggap tidak memelihara dan memberikan pengetahuan yang dimiliki seorang auditor juga keterampilan untuk menjamin seorang klien atas menerima jasa professional yang kompeten sehingga menyebabkan munculnya keraguan atas opini audit dan akibatnya masyarakat mengkritik profesi auditor yang dianggap kurang kompeten (Hutabarat, 2012). Kualitas audit ini penting karena dengan kualitas audit yang tinggi maka akan dihasilkan laporan keuangan yang dapat dipercaya sebagai dasar pengambilan keputusan yang secara tidak langsung juga menggambarkan kinerja dari auditor. Selain itu, kekhawatiran akan merebaknya skandal keuangan dapat mengikis kepercayaan publik terhadap laporan keuangan auditan dan profesi auditor (Mutiara, 2014).

Hal lainnya yang dapat meningkatkan keberhasilan dan kinerja auditor adalah kepuasan. Peningkatan kepuasan kerja bagi auditor berkaitan dengan pemenuhan harapan kerja dalam melakukan pemeriksaan. Banyaknya pemeriksaan yang dilakukan (overload) dan risiko yang dihadapi auditor dalam melakukan audit, mejadikan seorang auditor seringkali sukar untuk dapat mencapai tingkat kepuasan kerja. Menurut Gautama dan Arfan (2010) hakikat kepuasan kerja adalah perasaan senang atau tidak senang yang relatif berbeda dari pemikiran yang objektif dan keinginan perilaku. Perasaan senang ataupun tidak senang ini muncul disebabkan karena pada saat karyawan bekerja mereka membawa serta keinginan, kebutuhan, dan pengalaman masa lalu yang membentuk harapan kerja mereka.

Dengan demikian dapat dikatakan bahwa semakin tinggi harapan kerja ini dapat terpenuhi, maka semakin tinggi tingkat kepuasan kerja yang dirasakan oleh auditor. Seorang auditor yang mempunyai tingkat kepuasan kerja tinggi akan menunjukkan kinerjanya dengan baik pula. Apabila kepuasan kerja seseorang rendah maka akan berakibat buruk bagi instansi tempatnya bekerja. 


\section{TINJAUAN PUSTAKA}

\subsection{Motivasi}

Sutrisno (2013:109) mengemukakan motivasi adalah faktor yang mendorong seseorang untuk melakukan suatu aktivitas tertentu, motivasi sering kali diartikan pula sebagai faktor pendorong perilaku seseorang. Mangkunegara (2012:61) juga mengemukakan motivasi adalah kondisi atau energi yang menggerakkan diri karyawan yang terarah atau tertuju untuk mencapai tujuan organisasi perusahaan. Dapat diambil kesimpulan bahwa motivasi adalah dorongan dalam diri seseorang dalam usahanya memenuhi keinginan, maksud dan tujuan. Motivasi dapat pula dikatakan sebagai energi untuk membangkitkan dorongan dalam diri seseorang (Bahri, 2010).

\subsection{Kompetensi Auditor}

Menurut Suhayati dan Rahayu (2010:2) menjelaskan kompetensi adalah auditor harus mempunyai kemampuan, ahli dan berpengalaman dalam memahami kriteria dan dalam menentukan jumlah bahan bukti yang dibutuhkan untuk dapat mendukung kesimpulan yang akan diambil. Pernyataan Standar Pemeriksaan dalam SPKN Nomor 01 Tahun 2017 juga menyebutkan bahwa pemeriksa yang ditugaskan untuk melaksanakan Pemeriksaan menurut standar pemeriksaan harus secara kolektif memiliki kompetensi:

a. latar belakang pendidikan, keahlian dan pengalaman, serta pengetahuan tentang standar pemeriksaan yang dapat diterapkan terhadap jenis pemeriksaan yang ditugaskan;

b. pengetahuan umum tentang lingkungan entitas, program, dan kegiatan yang diperiksa (objek pemeriksaan);

c. keterampilan berkomunikasi secara jelas dan efektif, baik secara lisan maupun tulisan; dan

d. keterampilan yang memerlukan pengetahuan khusus dalam bidang tertentu sesuai dengan pemeriksaan yang dilaksanakan.

\subsection{Kepuasan Kerja}

Kepuasan kerja menurut Ahmadi dan Hermawan (2013:15) adalah keadaan emosional yang menyenangkan atau tidak menyenangkan terhadap pekerjaan, kepuasan kerja mencerminkan perasaan seeorang terhadap terhadap pekerjaannya. Richard, Robert dan Gordon $(2012: 312,337)$ menegaskan bahwa kepuasan kerja berhubungan dengan perasaan atau sikap seseorang mengenai pekerjaan itu sendiri, gaji, kesempatan promosi atau pendidikan, pengawasan, rekan kerja, beban kerja dan lain-lain.

\subsection{Kinerja Auditor Eksternal}

Menurut Mulyadi (2002) dalam Ulum (2015) kinerja auditor adalah suatu keadaan dimana akuntan publik yang melaksanakan penugasan pemeriksaan (examination) secara obyektif atas laporan keuangan suatu perusahaan atau organisasi lain dengan tujuan untuk menentukan apakah laporan keuangan tersebut menyajikan secara wajar sesuai dengan prinsip akuntansi yang berlaku umum, dalam semua hal yang material, posisi keuangan dan hasil usaha perusahaan. Kinerja (prestasi kerja) dapat diukur melalui pengukuran tertentu (standar) dimana kualitas adalah berkaitan dengan mutu kerja yang dihasilkan, sedangkan kuantitas adalah jumlah hasil kerja yang dihasilkan dalam kurun waktu tertentu, dan ketepatan waktu adalah kesesuaian waktu yang telah direncanakan.

\subsection{Pengaruh Motivasi Intrinsik Terhadap Kinerja Auditor Eksternal}

Peningkatan semangat dan gairah kerja karyawan dapat dilakukan dengan memberikan motivasi kerja yang tepat bagi karyawan dan dapat memberikan kesempatan bagi karyawan untuk meningkatkan kemampuan dan keterampilannya. Dengan adanya pemberian motivasi kerja maka karyawan diharapkan dapat meningkatkan kinerjanya (Siagian, 2014). Husin dan Umbara (2017) mengatakan motivasi dapat di jadikan sebagai pemberian daya perangsang kepada auditor agar dapat bekerja dengan segala upaya karena motivasi merupakan suatu kondisi yang menggerakkan manusia ke suatu tujuan tertentu. Penelitian yang dilakukan oleh 
Putri (2015) menunjukkan bahwa motivasi berpengaruh positif dan signifikan terhadap peningkatan kinerja auditor. Hasil tersebut menunjukkan adanya hubungan erat antara motivasi dan peningkatan kinrja auditor.

Dari uraian tersebut maka hipotesis yang dirumuskan:

$\mathrm{H}_{1}$ : Motivasi Intrinsik berpengaruh terhadap peningkatan kinerja auditor eksternal pada Kantor BPK-RI Provinsi Sulut.

\subsection{Pengaruh Kompetensi Auditor Terhadap Kinerja Auditor Eksternal}

Dalam melaksanakan proses audit, auditor membutuhkan pengetahuan, pengalaman, pendidikan dan pelatihan yang baik karena dengan hal itu auditor menjadi lebih mampu memahami kondisi keuangan dan laporan keuangan kliennya dan akan menghasilkan kualitas yang baik. Oleh karena itu dapat dipahami bahwa seorang auditor yang kompeten atau yang memiliki pengetahuan, pendidikan, pengalaman dan pelatihan yang memadai akan lebih memahami dan mengetahui berbagai masalah laporan keuangan secara lebih mendalam harus secara terus menerus mengikuti perkembangan yang terjadi dalam bisnis dan profesinya dan harus mempelajari, mamahami dan menerapkan ketentuan-ketentuan baru dalam standar auditing yang ditetapkan oleh organisasi profesi untuk meningkatkan kualitas audit dan hal ini tentu saja berpengaruh langsung terhadap kinerjanya. Penelitian yang pernah dilakukan oleh Nurnaluri \& Cahyaniza (2017) menunjukkan hasil positif antara kompetensi auditor dan peningkatan kinerjanya atau dengan kata lain semakin tinggi tingkat kompetensi yang dimiliki seorang auditor maka semakin baik pula kinerja yang dicapai.

Dari uraian tersebut maka hipotesis yang dirumuskan:

$\mathrm{H}_{2}$ : Kompetensi auditor berpengaruh terhadap peningkatan kinerja auditor eksternal pada Kantor BPK-RI Provinsi Sulut.

\subsection{Pengaruh Kepuasan Kerja Terhadap Kinerja Auditor Eksternal.}

Keberhasilan dan kinerja seorang auditor dalam melakukan pemeriksaan keuangan juga sangat ditentukan oleh adanya peningkatan kepuasan kerja. Peningkatan kepuasan kerja bagi auditor berkaitan dengan pemenuhan harapan kerja dalam melakukan pemeriksaan. Banyaknya pemeriksaan yang dilakukan (overload) dan risiko yang dihadapi auditor dalam melakukan audit, mejadikan seorang auditor sukar untuk dapat mencapai tingkat kepuasan kerja. Seorang auditor yang mempunyai tingkat kepuasan kerja tinggi akan menunjukkan kinerjanya dengan baik pula. Penelitian oleh Gautama \& Arfan (2010) menunjukkan bahwa kepuasan kerja berpengaruh positif terhadap peningkatan kinerja auditor.

Dari uraian tersebut maka hipotesis yang dirumuskan:

$\mathrm{H}_{3}$ : Kepuasan kerja berpengaruh terhadap peningkatan kinerja auditor eksternal pada Kantor BPK-RI Provinsi Sulut.

\subsection{Pengaruh Motivasi Intrinsik, Kompetensi Auditor dan Kepuasan Kerja Terhadap Kinerja Auditor Eksternal}

Motivasi dapat di jadikan sebagai pemicu auditor agar dapat bekerja dengan segala upaya karena motivasi merupakan suatu kondisi yang menggerakkan manusia ke suatu tujuan tertentu. Bila auditor termotivasi, ia akan berusaha sekuat tenaga untuk mewujudkan apa yang menjadi keinginannya. Ketika auditor termotivasi untuk meningkatkan kinerjanya, ia juga akan meningkatkan kualitas diri. Oleh karena itu, peningkatan kompetensi auditor dalam hal ini auditor BPK senantiasa harus menjadi perhatian khusus, jika ingin menghasilkan kinerja yang maksimal khsusnya dalam pengawasan keuangan daerah. Di samping motivasi intrinsik dan kompetensi auditor, kepuasan kerja juga merupakan faktor penting dalam meningkatkan kinerja auditor. Seorang auditor yang mempunyai tingkat kepuasan kerja tinggi akan menunjukkan kinerjanya dengan baik pula.

Dari uraian tersebut maka hipotesis yang dirumuskan:

$\mathrm{H}_{4}$ : Motivasi intrinsik, kompetensi auditor, dan kepuasan kerja berpengaruh secara simultan terhadap kinerja auditor eksternal pada kantor BPK-RI Provinsi Sulut. 


\section{METODE PENELITIAN}

\subsection{Jenis dan Sumber Data}

Jenis penelitian yang digunakan adalah penelitian kuantitatif. Berdasarkan hubungan antar variabel, maka penelitian ini merupakan penelitian korelasional, yaitu untuk menentukan apakah terdapat hubungan antara variabel independen yaitu motivasi intrinsik $\left(\mathrm{X}_{1}\right)$, kompetensi auditor $\left(\mathrm{X}_{2}\right)$ dan kepuasan kerja $\left(\mathrm{X}_{3}\right)$ terhadap variabel dependen yaitu kinerja auditor eksternal (Y). Sumber data yang digunakan dalam penelitian ini adalah data primer yang secara langsung bersumber dari responden tanpa ada perantara, dalam hal ini adalah jawaban atas pertanyaan dan pernyataan yang ada dalam kuesioner.

\subsection{Sampel dan Teknik Pengambilan Sampel}

Populasi penelitian ini adalah seluruh auditor yang bekerja di kantor Badan Pemeriksa Keuangan (BPK) RI Provinsi Sulawesi Utara yang berjumlah 62 orang. Sedangkan sampel yang diambil adalah 50 auditor yang bekerja di Kantor Badan Pemeriksa Keuangan (BPK) RI Provinsi Sulawesi Utara. Teknik pengambilan sampel yang digunakan adalah nonprobability sampling, dengan menggunakan purposive sampling, yaitu teknik pengambilan sampel berdasarkan kriteria yang telah ditentukan (Kuncoro:2014). Berdasarkan teknik pengambilan sampel tersebut, maka kriteria yang digunakan dalam penelitian ini adalah sebagai berikut:

1. Responden memiliki jenjang pendidikan minimal S1.

2. Responden telah menekuni pekerjaannya sebagai auditor selama minimal satu tahun.

\subsection{Metode Analisis}

Metode analisis data yang digunakan dalam penelitian ini adalah analisis regresi linier berganda (Multiple Regression Analysis) dengan bantuan program Statistical Product and Service Solution (SPSS) versi 23. Analisis ini dimaksudkan untuk mengetahui pengaruh beberapa variabel bebas terhadap variabel terikat. Analisis regresi linear berganda diawali dengan uji kualitas data, uji ini untuk mengetahui ketepatan alat ukur dalam mengukur objek yang diteliti. Model analisis regresi memerlukan uji asumsi klasik, untuk menginterpretasikan data agar lebih relevan dalam menganalisis. Uji asumsi klasik yang digunakan adalah uji normalitas, uji multikolinearitas, dan uji heteroskedastisitas.

\section{HASIL ANALISIS DAN PEMBAHASAN}

\subsection{Hasil Analisis}

\subsubsection{Uji Kualitas Data}

A. Uji Validitas

Sebuah kuesioner dapat dinyatakan valid jika nilai $r_{\text {hitung }}>r_{\text {tabel }}$ dan atau nilai sig < 0,05 maka item pertanyaan tersebut dianggap valid (Thoifah, 2015: 111).

\begin{tabular}{ccccc} 
Tabel 4.1 Hasil Uji Validitas Motivasi Intrinsik $\left(\mathbf{X}_{\mathbf{1}}\right)$ \\
\hline $\begin{array}{c}\text { Nomor } \\
\text { Pertanyaan }\end{array}$ & $\mathbf{r}_{\text {hitung }}$ & $\mathbf{r}_{\text {tabel }}$ & $\mathbf{5 \%}$ & Keterangan \\
\hline 1 & 0,671 & 0,312 & 0,05 & Valid \\
2 & 0,682 & 0,312 & 0,05 & Valid \\
3 & 0,672 & 0,312 & 0,05 & Valid \\
4 & 0,497 & 0,312 & 0,05 & Valid \\
5 & 0,405 & 0,312 & 0,05 & Valid \\
6 & 0,615 & 0,312 & 0,05 & Valid \\
7 & 0,515 & 0,312 & 0,05 & Valid \\
8 & 0,461 & 0,312 & 0,05 & Valid \\
9 & 0,429 & 0,312 & 0,05 & Valid \\
10 & 0,543 & 0,312 & 0,05 & Valid \\
\hline
\end{tabular}

Sumber: Data olahan SPSS (2018) 
Tabel 4.2 Hasil Uji Validitas Kompetensi Auditor $\left(\mathbf{X}_{2}\right)$

\begin{tabular}{ccccc}
\hline $\begin{array}{c}\text { Nomor } \\
\text { Pertanyaan }\end{array}$ & $\mathbf{r}_{\text {hitung }}$ & $\mathbf{r}_{\text {tabel }}$ & $\mathbf{5 \%}$ & Keterangan \\
\hline 1 & 0,532 & 0,312 & 0,05 & Valid \\
2 & 0,619 & 0,312 & 0,05 & Valid \\
3 & 0,694 & 0,312 & 0,05 & Valid \\
4 & 0,586 & 0,312 & 0,05 & Valid \\
5 & 0,653 & 0,312 & 0,05 & Valid \\
6 & 0,631 & 0,312 & 0,05 & Valid \\
7 & 0,528 & 0,312 & 0,05 & Valid \\
8 & 0,661 & 0,312 & 0,05 & Valid \\
9 & 0,422 & 0,312 & 0,05 & Valid \\
10 & 0,381 & 0,312 & 0,05 & Valid \\
\hline \multicolumn{5}{c}{ Sumber: Data olahan SPSS (2018) } \\
\hline
\end{tabular}

Tabel 4.3 Hasil Uji Validitas Kepuasan Kerja $\left(X_{3}\right)$

\begin{tabular}{ccccc}
\hline $\begin{array}{c}\text { Nomor } \\
\text { Pertanyaan }\end{array}$ & $\mathbf{r}_{\text {hitung }}$ & $\mathbf{r}_{\text {tabel }}$ & $\mathbf{5 \%}$ & Keterangan \\
\hline 1 & 0,518 & 0,312 & 0,05 & Valid \\
2 & 0,491 & 0,312 & 0,05 & Valid \\
3 & 0,427 & 0,312 & 0,05 & Valid \\
4 & 0,671 & 0,312 & 0,05 & Valid \\
5 & 0,638 & 0,312 & 0,05 & Valid \\
6 & 0,490 & 0,312 & 0,05 & Valid \\
7 & 0,424 & 0,312 & 0,05 & Valid \\
8 & 0,417 & 0,312 & 0,05 & Valid \\
9 & 0,367 & 0,312 & 0,05 & Valid \\
10 & 0,491 & 0,312 & 0,05 & Valid \\
\hline
\end{tabular}

Sumber: Data olahan SPSS (2018)

Tabel 4.4 Hasil Uji Validitas Kinerja Auditor Eksternal (Y)

\begin{tabular}{ccccc}
\hline $\begin{array}{c}\text { Nomor } \\
\text { Pertanyaan }\end{array}$ & $\mathbf{r}_{\text {hitung }}$ & $\mathbf{r}_{\text {tabel }}$ & $\mathbf{5 \%}$ & Keterangan \\
\hline 1 & 0,687 & 0,312 & 0,05 & Valid \\
2 & 0,636 & 0,312 & 0,05 & Valid \\
3 & 0,548 & 0,312 & 0,05 & Valid \\
4 & 0,775 & 0,312 & 0,05 & Valid \\
5 & 0,634 & 0,312 & 0,05 & Valid \\
6 & 0,683 & 0,312 & 0,05 & Valid \\
7 & 0,600 & 0,312 & 0,05 & Valid \\
8 & 0,448 & 0,312 & 0,05 & Valid \\
9 & 0,459 & 0,312 & 0,05 & Valid \\
10 & 0,553 & 0,312 & 0,05 & Valid \\
\hline \multicolumn{5}{c}{ Sumber: Data olahan SPSS (2018) }
\end{tabular}

Uji validitas menunjukkan bahwa semua pertanyaan untuk masing-masing variabel memiliki kriteria valid dengan nilai $r_{\text {hitung }}$ lebih besar dari $r_{\text {tabel }}$ sehingga semua pertanyaan tersebut dapat digunakan untuk mengukur masing-masing variabel. 


\section{B. Uji Reliabilitas}

Uji reliabilitas dimaksudkan untuk menguji konsistensi kuesioner dalam mengukur suatu konstruk yang sama atau stabilitas kuesioner jika digunakan dari waktu ke waktu (Ghozali, 2011). Uji reliabilitas dilakukan dengan cara menghitung koefisien cronbach's alpha > 0,60 maka dapat disimpulkan bahwa instrumen penelitian tersebut reliabel.

Tabel 4.5 Hasil Uji Reliabilitas

\begin{tabular}{ccc}
\hline Variabel & Cronbach's Alpha & Keterangan \\
\hline Motivasi Intrinsik & 0,748 & Reliabel \\
Kompetensi Auditor & 0,756 & Reliabel \\
Kepuasan Kerja & 0,653 & Reliabel \\
Kinerja Auditor & 0,802 & Reliabel \\
\hline
\end{tabular}

Sumber : Data olahan SPSS(2018)

Tabel 4.5 menunjukkan semua pertanyaan untuk setiap variabel setiap variabel memiliki nilai koefisien cronbach's alpha $>0,60$, maka dapat disimpulkan bahwa seluruh pertanyaan dalam kuesioner reliabel.

\subsubsection{Uji Asumsi Klasik}

\section{A. Uji Normalitas}

Uji normalitas dalam penelitian ini menggunakan rumus Kolmogorov-Smirnov. Dasar pengambilan keputusan untuk uji normalitas yaitu jika nilai signifikansi lebih besar dari 0,05 maka data tersebut berdistribusi normal dan sebaliknya.

Tabel 4.6 Hasil Uji Normalitas One-Sample Kolmogorov-Smirnov Test

\begin{tabular}{ccr}
\hline & & $\begin{array}{c}\text { Unstandardized } \\
\text { Residual }\end{array}$ \\
\hline Normal & $\mathrm{N}$ & 40 \\
Parameters $^{\mathrm{a}, \mathrm{b}}$ & Mean &, 0000000 \\
& Std. Deviation & 2,31969412 \\
Most Extreme & Absolute &, 101 \\
Differences & Positive &, 101 \\
Test Statistic &,- 084 \\
Asymp. Sig. (2-tailed) &, 101 \\
Sumber : Data olahan SPSS(2018) &, $200^{\mathrm{c}, \mathrm{d}}$ \\
\hline
\end{tabular}

Tabel 4.6 menunjukkan nilai signifikansi > 0,05. Hal ini dibuktikan dengan nilai asymp. Sig 0,200 > 0,05, menunjukkan bahwa data telah berdistribusi secara normal.

\section{B. Uji Multikolinearitas}

Uji multikolinearitas dilakukan untuk mendeteksi gejala korelasi antara variabel independen yang satu dengan variabel independen yang lain. Dengan melihat nilai tolerance dan nilai Variance Inflation Factors (VIF). Jika nilai tolerance $>0,10$ dan VIF $<10$ maka dinyatakan tidak ada korelasi sempurna antara variabel independen (Ghozali, 2011). 
Tabel 4.7 Hasil Uji Multikolinearitas

Coefficients $^{\mathrm{a}}$

\begin{tabular}{|c|c|c|c|}
\hline & \multirow[b]{2}{*}{ Model } & \multicolumn{2}{|c|}{ Collinearity Statistics } \\
\hline & & Tolerance & VIF \\
\hline \multirow[t]{4}{*}{1} & (Constant) & & \\
\hline & Motivasi Intrinsik & ,907 & 1,102 \\
\hline & Kompetensi Auditor & ,909 & 1,100 \\
\hline & Kepuasan Kerja & ,975 & 1,025 \\
\hline
\end{tabular}

Sumber : Data olahan SPSS(2018)

Tabel 4.7 menunjukan nilai tolerance setiap variabel independen $>0,10$ dan nilai VIF setiap variabel independen $<10$, sehingga penelitian ini tidak mengalami multikolinearitas, sehingga salah satu syarat uji regresi berganda telah terpenuhi.

C. Uji Heteroskedastisitas

Uji heteroskedastisitas dalam penelitian ini menggunakan uji Glesjer. Apabila koefisien signifikansi lebih besar dari tingkat signifikansi yang ditetapkan, maka dapat disimpulkan tidak terjadi heteroskedastisitas (Thoifah, 2015: 222).

\section{Tabel 4.8 Hasil Uji Heteroskedastisitas dengan Uji Glesjer}

\section{Coefficients $^{\mathrm{a}}$}

\begin{tabular}{ccc}
\hline & Model & Sig. \\
\hline 1 & (Constant) &, 530 \\
& Motivasi Intrinsik &, 267 \\
& Kompetensi Auditor &, 419 \\
& Kepuasan Kerja &, 762 \\
\hline & Sumber : Data olahan SPSS(2018)
\end{tabular}

Tabel 4.8 menunjukkan signifikansi variabel motivasi intrinsik 0,267, variabel kompetensi auditor sebesar 0,419 dan variabel kepuasan kerja 0,762 menunjukkan signifikansi > 0,05. Maka dapat disimpulkan bahwa tidak terjadi heteroskedastisitas pada model regresi.

\subsubsection{Analisis Regresi Linear Berganda}

\section{Tabel 4.9 Hasil Analisis Regresi}

Coefficients $^{a}$

\begin{tabular}{|c|c|c|c|c|c|c|}
\hline & \multirow[b]{2}{*}{ Model } & \multicolumn{2}{|c|}{$\begin{array}{l}\text { Unstandardized } \\
\text { Coefficients }\end{array}$} & \multirow{2}{*}{$\begin{array}{c}\begin{array}{c}\text { Standardized } \\
\text { Coefficients }\end{array} \\
\text { Beta } \\
\end{array}$} & \multirow[b]{2}{*}{$t$} & \multirow[b]{2}{*}{ Sig. } \\
\hline & & B & $\begin{array}{l}\text { Std. } \\
\text { Error }\end{array}$ & & & \\
\hline \multirow[t]{4}{*}{1} & (Constant) & $-3,439$ & 9,349 & &,- 368 & ,715 \\
\hline & Motivasi Intrinsik & ,383 &, 121 & ,406 & 3,159 &, 003 \\
\hline & Kompetensi Auditor & ,376 & ,132 & ,366 & 2,850 &, 007 \\
\hline & Kepuasan Kerja & ,314 &, 140 & 278 & 2,245 & ,031 \\
\hline
\end{tabular}

a. Dependent Variable: Kinerja Auditor

Sumber : Data olahan SPSS(2018)

Berdasarkan tabel 4.9 diperoleh persamaan regresi berganda sebagai berikut:

$$
Y=-3,439+0,383 X_{1}+0,376 X_{2}+0,314 X_{3}+\varepsilon
$$


Dengan interpretasi bahwa:

1. Nilai konstanta $(\alpha)$ sebesar $-3,439$ bernilai negatif artinya jika variabel motivasi intrinsik, kompetensi auditor dan kepuasan kerja dianggap sama dengan 0, maka skor kinerja auditor eksternal akan semakin berkurang.

2. Variabel motivasi intrinsik $\left(X_{1}\right)$ memiliki nilai koefisien regresi $\left(\beta_{1}\right)$ sebesar 0,383 dan bernilai positif, menunjukkan bahwa motivasi intrinsik memiliki pengaruh positif terhadap kinerja auditor eksternal.

3. Variabel kompetensi auditor $\left(\mathrm{X}_{2}\right)$ memiliki nilai koefisien regresi $\left(\beta_{2}\right)$ sebesar 0,376 dan bernilai positif, menunjukkan bahwa kompetensi auditor memiliki pengaruh positif terhadap kinerja auditor eksternal.

4. Variabel kepuasan kerja $\left(\mathrm{X}_{3}\right)$ memiliki koefisien regresi $\left(\beta_{3}\right)$ sebesar 0,314 dan bernilai positif, menunjukkan bahwa kepuasan kerja memiliki pengaruh positif terhadap kinerja auditor eksternal.

\section{A. Uji Simultan (Uji F)}

Uji $F$ digunakan untuk mengetahui apakah secara simultan koefisien variabel independen mempunyai pengaruh nyata atau tidak terhadap variabel dependen.

Tabel 4.10 Hasil Uji Simultan (Uji F)

ANOVA $^{\mathrm{a}}$

\begin{tabular}{ccccccc}
\hline & Model & $\begin{array}{c}\text { Sum of } \\
\text { Squares }\end{array}$ & Df & $\begin{array}{c}\text { Mean } \\
\text { Square }\end{array}$ & F & Sig. \\
\hline 1 & Regression & 179,917 & 3 & 59,972 & 10,288 &, $000^{\mathrm{b}}$ \\
& Residual & 209,858 & 36 & 5,829 & & \\
& Total & 389,775 & 39 & & & \\
\hline
\end{tabular}

Sumber : Data olahan SPSS(2018)

Tingkat signifikansi dalam penelitian ini adalah 0,05. Adapun metode dalam penentuan $\mathrm{F}_{\text {tabel }}$ menggunakan ketentuan $\mathrm{N} 1=\mathrm{k}-1$ dan $\mathrm{N} 2=\mathrm{n}-\mathrm{k}$, sehingga didapat nilai $\mathrm{F}_{\text {tabel }}$ sebesar 3,25.

Tabel 4.10 menunjukkan hasil analisis menggunakan $\mathrm{F}_{\text {hitung }}=10,288>\mathrm{F}_{\text {tabel }}=3,25$ dengan signifikansi $0,000<0,05$, maka dapat disimpulkan variabel motivasi intrinsik, kompetensi auditor dan kepuasan kerja secara simultan berpengaruh signifikan terhadap kinerja auditor eksternal.

\section{B. Uji Parsial (uji t)}

Uji t digunakan untuk menguji apakah hipotesis yang diajukan dalam penelitian ini diterima atau tidak dengan mengetahui apakah variabel independen secara individual mempengaruhi variabel dependen.

Tabel 4.11 Hasil Uji Parsial (uji t)

Coefficients $^{\mathrm{a}}$

\begin{tabular}{|c|c|c|c|c|c|c|}
\hline & \multirow{2}{*}{ Model } & \multicolumn{2}{|c|}{ Unstandardized Coefficients } & \multirow{2}{*}{$\begin{array}{c}\text { Standardized } \\
\text { Coefficients }\end{array}$} & \multirow{2}{*}{$\mathrm{t}$} & \multirow{2}{*}{ Sig. } \\
\hline & & B & Std. Error & & & \\
\hline \multirow{4}{*}{1} & (Constant) & $-3,439$ & 9,349 & &,- 368 & ,715 \\
\hline & Motivasi Intrinsik & ,383 & , 121 & ,406 & 3,159 & ,003 \\
\hline & Kompetensi Auditor & 376 & ,132 & ,366 & 2,850 & ,007 \\
\hline & Kepuasan Kerja & 314 & 140 & 278 & 2,245 & 031 \\
\hline
\end{tabular}

Sumber : Data olahan SPSS (2018) 
Metode dalam penentuan $t_{\text {tabel }}$ menggunakan $\mathrm{df}=\mathrm{n}-\mathrm{k}-1(\mathrm{df}=40-3-1=36)$, sehingga didapat nilai $t_{\text {tabel }}$ sebesar 1,688.

Berdasarkan tabel 4.11, variabel motivasi intrinsik menunjukkan nilai $\mathrm{t}_{\text {hitung }}$ sebesar $3,159>t_{\text {tabel }}$ sebesar 1,688 dengan signifikansi sebesar $0,003<0,05$. Hal ini menunjukkan bahwa secara parsial motivasi intrinsik memiliki pengaruh signifikan terhadap kinerja auditor eksternal. Jadi, hipotesis $\mathrm{Ha}_{1}$ diterima dan $\mathrm{Ho}_{1}$ ditolak.

Variabel kompetensi auditor auditor menunjukkan nilai $t_{\text {hitung }}$ sebesar $2,850>t_{\text {tabel }}$ sebesar 1,688 dengan signifikansi sebesar 0,007 < 0,05. Hal ini menunjukkan bahwa secara parsial kompetensi auditor memiliki pengaruh signifikan terhadap kinerja auditor eksternal. Jadi, hipotesis $\mathrm{Ha}_{2}$ diterima dan $\mathrm{Ho}_{2}$ ditolak.

Variabel kepuasan kerja menunjukkan nilai $t_{\text {hitung }}$ sebesar 2,245 $>t_{\text {tabel }}$ sebesar 1,688 dengan signifikansi 0,031<0,05. Hal ini menunjukkan bahwa secara parsial kepuasan kerja memiliki pengaruh signifikan terhadap kinerja auditor eksternal. Jadi hipotesis $\mathrm{Ha}_{3}$ diterima dan $\mathrm{Ho}_{3}$ ditolak.

\section{Koefisien Determinasi}

Menurut Ghozali (2013: 197), koefisien determinasi $\left(\mathrm{R}^{2}\right)$ pada intinya mengukur seberapa jauh kemampuan model dalam menerangkan variasi variabel dependen.

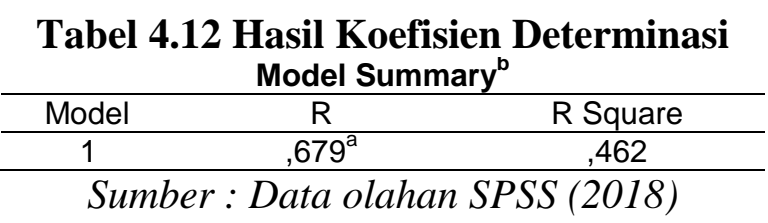

Berdasarkan tabel 4.12 besarnya R Square adalah 0,462 nilai ini menunjukkan, 46,2\% variasi kinerja auditor pada BPK RI Perwakilan Provinsi Sulawesi Utara dapat dijelaskan oleh variabel motivasi intrinsik $\left(\mathrm{X}_{1}\right)$, kompetensi auditor $\left(\mathrm{X}_{2}\right)$ dan kepuasan kerja $\left(\mathrm{X}_{3}\right)$ sisanya 53,8\% dijelaskan oleh variabel lain yang tidak diteliti dalam penelitian ini.

\subsection{Pembahasan}

Hasil pengujian hipotesis pertama menunjukkan, semakin besar motivasi intrinsik yang dimiliki auditor, maka semakin tinggi pula peningkatan kinerja auditor BPK RI Perwakilan Provinsi Sulawesi Utara.

Hasil pengujian hipotesis kedua menunjukkan, semakin tinggi tingkat kompetensi auditor maka semakin tinggi pula kinerja auditor BPK RI Perwakilan Provinsi Sulawesi Utara.

Hasil pengujian hipotesis ketiga menunjukkan, semakin tinggi tingkat kepuasan kerja auditor maka semakin tinggi pula kinerja yang dicapai auditor BPK RI Perwakilan Provinsi Sulawesi Utara.

Hasil pengujian hipotesis keempat menunjukkan bahwa semakin besar motivasi intrinsik auditor, semakin tinggi kompetensi yang diimiliki seorang auditor dan semakin tinggi tingkat kepuasan auditor terhadap pekerjaannya maka semakin tinggi pula kinerja yang dicapai auditor BPK RI Perwakilan Provinsi Sulawesi Utara.

\section{KESIMPULAN DAN SARAN}

\subsection{Kesimpulan}

Berdasarkan hasil penelitian dan pembahasan pada bab sebelumnya, maka disimpulkan bahwa:

1. Motivasi intrinsik $\left(\mathrm{X}_{1}\right)$ berpengaruh positif dan signifikan terhadap kinerja auditor eksternal (Y), sehingga hipotesis pertama diterima. Hal ini menunjukkan bahwa semakin tinggi motivasi intrinsik yang dimiliki auditor maka semakin tinggi tingkat 
prestasi kerja atau kinerja yang dicapai auditor. Dengan demikian, hipotesis pertama diterima.

2. Kompetensi auditor $\left(\mathrm{X}_{2}\right)$ berpengaruh positif dan signifikan terhadap kinerja auditor (Y). Hal ini menunjukkan bahwa bahwa jika seorang auditor memiliki tingkat kompetensi yang tinggi maka akan berpengaruh positif terhadap peningkatan kinerjanya. Dengan demikian, hipotesis kedua diterima.

3. Kepuasan kerja $\left(\mathrm{X}_{3}\right)$ diketahui berpengaruh positif dan signifikan terhadap kinerja auditor. Hal ini menunjukkan bahwa auditor dengan tingkat kepuasan yang tinggi terhadap pekerjaannya memiliki pengaruh positif terhadap peningkatan kinerjanya atau dengan kata lain semakin tinggi tingkat kepuasan kerja yang dimiliki auditor maka semakin tinggi pula peningkatan kinerjanya. Dengan demikian, hipotesis ketiga diterima

4. Variabel motivasi intrinsik, kompetensi auditor dan kepuasan kerja secara simultan berpengaruh signifikan terhadap kinerja auditor. Dengan demikian dapat disimpulkan bahwa motivasi intrinsik, kompetensi auditor dan kepuasan kerja memiliki pengaruh signifikan dalam meningkatkan kinerja auditor. Sehingga hipotesis keempat diterima.

\subsection{Saran}

Bagi BPK RI Perwakilan Provinsi Sulawesi Utara, sangat diharapkan untuk lebih memperhatikan faktor motivasi para auditor. Menumbuhkan motivasi dapat dilakukan dengan meningkatkan kesejahteraan. Bila auditor termotivasi ia akan berusaha sekuat tenaga untuk mewujudkan apa yang menjadi keinginannya. Dengan begitu auditor akan melakukan tugasnya dengan maksimal sehingga kinerjanya pun meningkat. Kompetensi yang dimiliki auditor juga perlu ditingkatkan. Adanya keahlian dan kemampuan dalam melaksanakan pemeriksaan akan dapat membantu auditor untuk mengetahui kekeliruan serta penyimpangan yang merupakan salah satu bagian dari kompetensi seorang auditor.

Bagi penelitian selanjutnya, penelitian ini masih membutuhkan beberapa perbaikan untuk dilakukan pada penelitian-penelitian selanjutnya yang masih memiliki keterkaitan dengan objek penelitian yang sejenis. Adapun beberapa saran perbaikan yakni, berkaitan dengan penambahan beberapa variabel lain yang digunakan dalam mengukur kinerja auditor. Sampel responden juga sebaiknya lebih diperluas untuk mendapatkan keterwakilan yang lebih besar atas populasi penelitian yang diteliti. Perluasan ini dapat berupa penambahan ruang lingkup geografis responden. Pemilihan waktu pembagian kuesioner juga perlu diperhatikan agar pengembalian kuesioner maksimal dan jumlah responden bertambah. Penelitian selanjutnya juga sebaiknya mencoba instrumen lain selain kuesioner agar data yang diperoleh lebih bisa menggambarkan objek penelitian secara keseluruhan.

\section{DAFTAR PUSTAKA}

Arep, Ishak \& Tanjung, Hendri. 2013. Manajemen Sumber Daya Manusia. Penerbit Universitas Trisakti: Jakarta.

Ahmadi, Candra \& Dadang Hermawan. 2013. E-business dan E-commerce. Yogyakarta: Penerbit Andi.

Badan Pemeriksa Keuangan RI. 2017. Standar Pemeriksaan Keuangan Negara No. 01 Tahun 2017. Peraturan Badan Pemeriksa Keuangan Republik Indonesia. Jakarta

Bahri, Syamsul. 2010. Pengaruh Motivasi, Tindakan Supervisi, dan Budaya Organisasi Terhadap Kinerja Auditor (Studi Empiris Pada Kantor Akuntan Publik di DKI Jakarta dan Tangerang Selatan). Skripsi Fakultas Ekonomi dan Bisnis Universitas Islam Negeri Syarif Hidayatullah. Jakarta. 
Efendy, Muh. Taufiq. 2010. Pengaruh Kompetensi, Independensi dan Motivasi Terhadap Kualitas Audit Aparat Inspektorat Dalam Pengawasan Keuangan Daerah. Jurnal. Program Magister Akuntansi. Universitas Diponegoro. Semarang.

Gautama S, Ibnu \& Arfan, Muhammad. 2010. Pengaruh Kepuasan Kerja, Profesionalisme, Dan Penerapan Teknologi Informasi Terhadap Kinerja Auditor (Studi Pada Kantor BPK RI Perwakilan Provinsi Aceh). Jurnal Telaah \& Riset Akuntansi Vol. 3. No. 2, Juli 2010 hal. 195-205.

Ghozali, Imam. 2013. Aplikasi Analisis Multivariat dengan Program IBM SPSS 21. Edisi Ketujuh. Universitas Dipenogoro. Semarang.

Husin \& Umbara, Bayu. 2017. Pengaruh Motivasi Kerja Terhadap Kinerja Auditor (Studi Pada Inspektorat Kota Kendari). Jurnal Akuntansi dan Keuangan Fakultas Ekonomi Dan Bisnis Universitas Halu Oleo.

Hutabarat, Goodman. 2012. Pengaruh Pengalaman Time Budget Pressure dan Etika Auditor Terhadap Kualitas Audit. Jurnal Ilmiah. Vol. 6. No. 1.

Kuncoro, Mudrajad. 2014. Metode Riset untuk Bisnis \& Ekonomi. Edisi Keempat. Erlangga. Jakarta.

Mangkunegara, A.A. Anwar Prabu. 2012. Manajemen Sumber Daya Manusia. Bandung: PT. Remaja Rosdakarya.

Mutiara, Sari. 2014. Pengaruh Kompetensi, Independensi dan Integritas Auditor Terhadap Kualitas Audit Pada Kantor Akuntan Publik di Kota Padang.

Nurnaluri, Sitti \& Cahyaniza. 2017. Pengaruh Kompetensi Auditor Terhadap Kinerja Auditor. Jurnal Akuntansi Fakultas Ekonomi dan Bisnis Universitas Halu Oleo. Sulawesi Tenggara.

Panjaitan, A \& Bambang Jatmiko. 2014. Pengaruh Motivasi, Stres, dan Rekan Kerja Terhadap Kinerja Auditor. Jurnal Bisnis dan Ekonomi Vol 5, No.1, Juni 2014, 1-18. Jakarta.

Putri, Dwi Melissa. 2015. Pengaruh Motivasi Kerja Dan Karakteristik Individu Terhadap Kinerja Auditor Yang Dimoderasi Oleh Faktor Lingkungan Kerja Dan Kompensasi (Studi Empiris pada karyawan Kantor Akuntan Publik di Semarang). Skripsi Fakultas Ekonomi Universitas Diponegoro.

Rich, Lepine \& Crawford. 2010. Job Engagement: Antecedents and effects on job performance. The Academy of Management Journal Vol. 53 No. 3

Richard L. Hughes, Robert C. Ginnet, dan Gordon J. Curphy. 2012. Leadership, Enhancing the Lessons of Experiences, Alih Bahasa: Putri Izzati. Jakarta: Salemba Humanika.

Siagian, Sondang P. 2014. Manajemen Sumber Daya Manusia. Jakarta: Bumi Aksara.

Suhayati, Ely \& Siti Kurnia Rahayu. 2010. AUDITING, Konsep Dasar dan Pedoman Pemeriksaan Akuntan Publik. Yogyakarta: Graha Ilmu.

Sutrisno, Edy. 2013. Manajemen Sumber Daya Manusia. Jakarta: Kencana Prenada Media Grup.

Thoifah, I'anatut. 2015. Statistika Pendidikan dan Metode Penelitian Kuantitatif. Madani. Malang.

Ulum, R. 2015. Pengaruh Gaya Kepemimpinan, Konflik Peran, dan Kelebihan Peran Terhadap Kinerja Auditor Dengan Kecerdasan Spiritual Sebagai Variabel Pemoderasi (Survey pada Kantor Akuntan Publik di Kota Bandung, Jawa Barat). Skripsi Fakultas Ekonomi dan Bisnis Universitas Islam Bandung. 